River in fall. It therefore appears that the Winnipeg River is the more important route by which Bald Eagles leave southeastern Manitoba, but the gradual nature of this withdrawal makes this aspect hard to assess.
'GERRARD, J.M. and D.R.M. HATCH. 1983. Bald Eagle migration through southern Saskatchewan and Manitoba and North Dakota. Blue Jay 41:146-154.

\title{
HUMMINGBIRDS AT ITUNA, SASKATCHEWAN
}

MARY F. BRENNAN, Box 104, Ituna, Saskatchewan. SOA 1 NO

My brother, Tom Yates and his neighbour put up feeders for the hummingbirds in Ituna. In July 1983 Tom discovered a hummingbird's nest in his front yard. It was situated on a horizontal branch of a black poplar tree just at eye level, and from the front was completely concealed by a large overhanging leaf.
On the outside the nest was covered with tiny flakes of grey lichen and it was lined with soft white cotton from some flower seed heads. The whole would have fit into an egg cup. The photograph of the nest was taken 11 July 1983. At that time there were 2 tiny white eggs in it about the size of small white beans, which soon hatched into

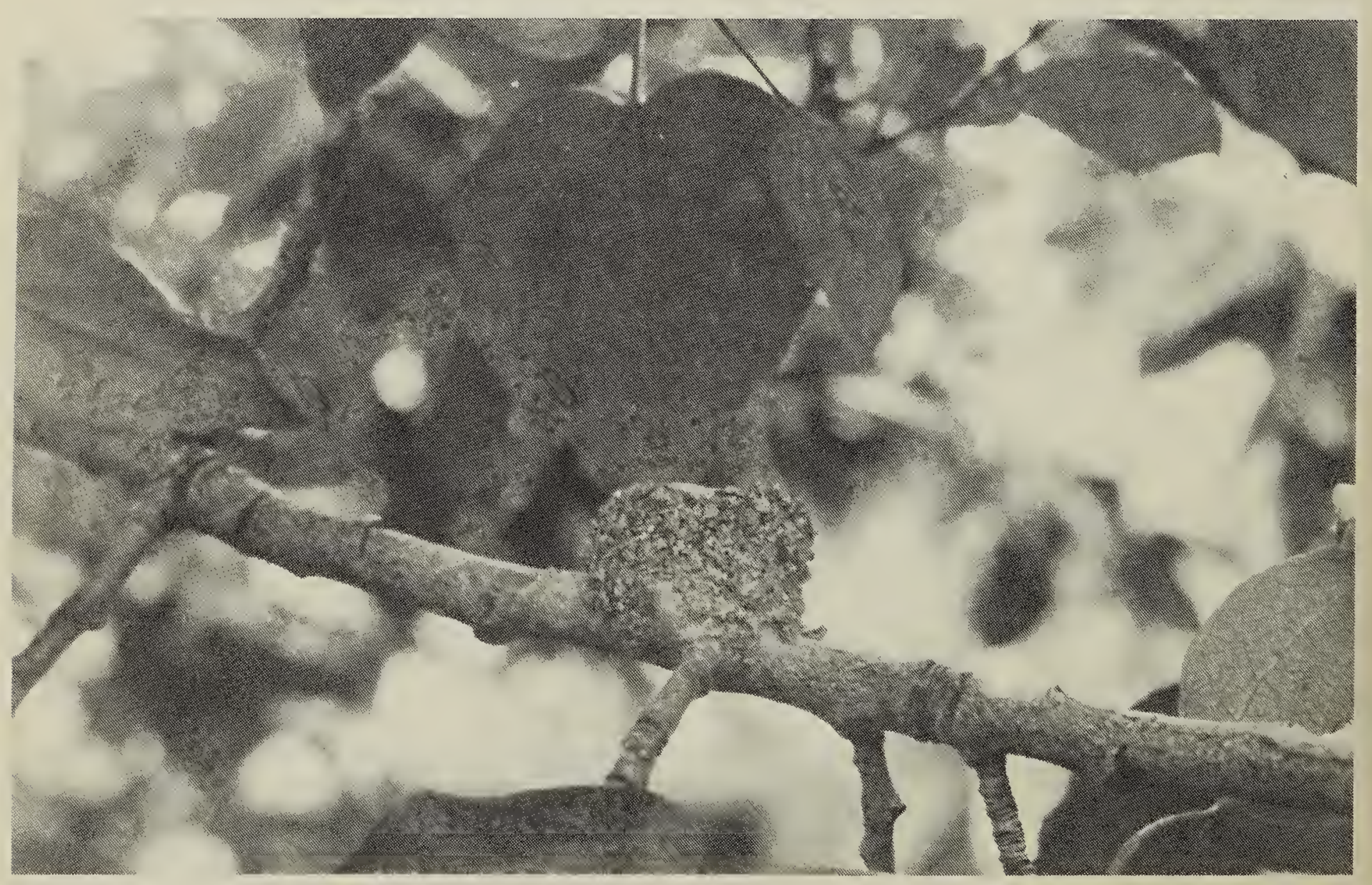


